\title{
ANALISIS GAYA BELAJAR DAN HUBUNGANNYA TERHADAP HASIL BELAJAR BIOLOGI SISWA PADA MATERI SISTEM REPRODUKSI MANUSIA
}

\author{
Siti Rahmah ${ }^{1^{*}}$, Cicik Suriani $^{1}$, Eni Susanti ${ }^{2}$ \\ ${ }^{1}$ Program Studi Pendidikan Biologi, FMIPA, Universitas Negeri Medan, Medan JI. Willem Iskandar Psr. V Medan \\ Estate, Medan, Indonesia, 20221 \\ ${ }^{2}$ SMA Negeri 4 Medan Jalan Gelas No. 12, Medan Indonesia, 20118 \\ *E-mail : rahmahsiti524@yahoo.co.id
}

\begin{abstract}
ABSTRAK
Penelitian ini bertujuan untuk menganalisis gaya belajar siswa serta hubungannya dengan hasil belajar biologi siswa kelas XI MIA SMA Negeri 4 Medan. Populasi dalam penelitian ini adalah seluruh kelas XI MIA SMA Negeri 4 Medan yang terbagi atas 10 kelas dengan jumlah siswa sebanyak 400 orang siswa. Sedangkan, sampel penelitian diambil secara purposive sampling yang berjumlah sebanyak 80 orang siswa. Metode penelitian yang digunakan dalam penelitian ini adalah deskriptif, dengan kuesioner (angket) dan tes sebagai alat pengumpul data penelitian. Dari hasil pengolahan data diketahui skor rata-rata gaya belajar sebesar 42,8 dan SD sebesar 3,44 sedangkan, rata-rata hasil belajar sebesar 79,1 dan SD sebesar 6,36. Untuk uji homogenitas Fhitung < Ftabel (0,540 $<1,447)$ Ho diterima maka data $X$ dan $Y$ termasuk homogen. Dari harga koefiesien korelasi diketahui rhitung $>$ rtabel $(2,237>0,220)$ sehingga data tersebut terdapat korelasi yang berarti dan positif antara gaya belajar dengan hasil belajar siswa dan perhitungan indeks determinasi sebesar $48 \%$ terhadap pencapaian hasil belajar siswa. Untuk pengujian hipotesis diperoleh $\mathrm{t}$ hitung $>\mathrm{t}$ tabel $(9,89>1,67)$ pada taraf $\alpha=0,05$ maka data termasuk Ha diterima sekaligus menolak Ho, sehingga dapat disimpulkan bahwa ada hubungan antara gaya belajar terhadap hasil belajar biologi siswa kelas XI MIA SMA Negeri 4 Medan.
\end{abstract}

Kata Kunci: Gaya Belajar, Hasil Belajar, Sistem Reproduksi Manusia

\section{ABSTRACT}

This research aims to analyze the learning styles of students and their relationship with the results of biology students learning class XI MIA SMA Negeri 4 Medan. The population in this study is the entire class XI MIA SMA Negeri 4 Medan which is divided into 10 classes with the number of students as many as 400 students. Meanwhile, the research sample is taken by purposive sample which amounted to 80 students. The research method used in this study is descriptive, with questionnaires and tests as a means of collecting research data. From the result of data processing, it is known that the average learning style score is 42,8 and SD 3,44 whereas, the average of learning result is 79,1 and SD is 6,36. For homogeneity test Farithmetic < Ftable $(0.540<1.447)$ Ho accepted then $X$ and $Y$ data including homogeneous. From correlation coefficient price known rarithmetic $>$ rtable $(2,237>0,220)$ so that data there is correlation which mean and positive between learning style with student learning result and calculation of index of determination equal to $48 \%$ to achievement of student learning result. To test the hypothesis obtained $\mathrm{t}$ arithmetic $>\mathrm{t}$ table $(9.89>1.67)$ on the stage $\alpha=0,05$ then the data including Ha accepted as well as reject $\mathrm{Ho}$, so it can be concluded that there is a relationship between learning styles to the biology learning outcomes of students of class XI MIA SMA Negeri 4 Medan.

Keyword: Learning Styles, Learning Outcomes, Human Reproductive System

\section{PENDAHULUAN}

Setiap anak yang dilahirkan memiliki karakteristik kemampuan otak yang berbeda-beda dalam menyerap, mengolah, dan menyampaikan informasi. Belajar merupakan aktivitas mental yang melibatkan kemampuan otak dalam menyerap, mengolah, dan menyampaikan informasi. Tentu saja bahwa belajar bukanlah hanya kegiatan menghafal saja. Banyak hal yang akan hilang (bersifat tidak permanen) dalam beberapa jam. Untuk mengingat apa yang telah diajarkan, peserta didik harus mengolah informasi tersebut dan memahaminya. 
Permasalahan yang masih sering muncul di dunia pendidikan adalah bagaimana cara seorang guru dalam mengembangkan, menciptakan, dan mengatur situasi yang memungkinkan siswa dalam melakukan proses belajar sehingga dapat menciptakan perubahan tingkah laku yang optimal pada diri siswa. Keberhasilan suatu proses belajar sangat ditentukan oleh banyak faktor, diantaranya adalah guru dan siswa. Guru merupakan komponen strategis dalam proses pembelajaran dan paling bertanggung jawab terhadap kualitas pendidikan. Dalam pembelajaran, guru harus mengakomodasi perbedaan gaya belajar (learning style) siswa ( Rachmawati et al 2013).

Hakikat Biologi tidak hanya berupa hafalan dan pemahaman akan konsep saja, tetapi juga berupa proses penerapan, bahkan penemuan, analisis, evaluasi, kreativitas, maka dalam pembelajarannya harus melibatkan siswa secara aktif untuk berinteraksi dengan objek konkret agar tujuan pembalajaran biologi dapat tercapai dan berjalan sebagaimana mestinya. Aktivitas belajar siswa merupakan syarat utama berlangsungnya proses pembelajaran (Wulandari 2011).

Gaya belajar menurut (Lestari 2012), merupakan cara yang lebih disukai dalam melakukan kegiatan berpikir, memproses dan mengerti suatu informasi. Tidak semua siswa memiliki gaya belajar yang sama, dimana setiap siswa memiliki gaya belajar yang alami dan nyaman bagi mereka masing-masing. Sedangkan menurut (DePorter et al 2011), gaya belajar seseorang adalah kombinasi dari bagaimana ia menyerap, dan kemudian mengatur serta mengolah informasi. Sedangkan menurut (Sriyanti 2013), gaya belajar merupakan cara anak didik belajar yang sudah menjadi kebiasaan, dan kebiasaan tersebut dianggap paling tepat baginya. Menurut (Sari 2014), salah satu karakteristik belajar yang berkaitan dengan menyerap, mengolah, dan menyampaikan informasi tersebut adalah gaya belajar peserta didik. Gaya belajar merupakan modalitas belajar yang sangat penting. Sebagian peserta didik bisa belajar dengan sangat baik hanya dengan cara melihat orang lain melakukannya. Mereka menyukai cara penyajian informasi yang runtut. Selama pelajaran, peserta didik tersebut suka menulis apa yang dikatakan pendidik/guru/dosen.
Peserta didik Visual ini berbeda dengan peserta didik Auditori yang mengandalkan kemampuan untuk mendengar. Sedangkan peserta didik Kinestetik lebih suka belajar dengan cara terlibat langsung.

Adanya perbedaan karakteristik dari gaya belajar siswa yang menuntut guru untuk lebih memahami strategi pembelajaran yang baik untuk setiap karakteristik murid yang ada. Michael Grinder, pengarang Risgting The Egucation Conveyor Belt, telah mengajarkan gaya-gaya belajar dan mengajar kepada banyak instruktur, la mencatat bahwa dalam setiap kelompok yang terdiri dari tiga puluh murid, sekitar dua puluh dua orang mampu belajar secara cukup efektif dengan cara visual, auditorial, dan kinestetik sehingga mereka tidak membutuhkan perhatian khusus, dari sisa delapan orang sekitar enam orang memilih satu modalitas belajar dengan sangat menonjol melebihi dua modalitas lainnya sehingga, setiap saat mereka harus selalu berusaha keras memahami perintah, kecuali jika perhatian khusus diberikan kepada mereka dengan menghadirkan cara yang mereka pilih, bagi orang-orang ini, mengetahui cara belajar terbaik mereka bisa berarti perbedaan antara keberhasilan dan kegagala, dua orang murid lainnya mempunyai kesulitan belajar karena sebabsebab eksternal (Hasrul 2009).

Adapun pembelajaran diarahkan pada penciptaan suasana aktif, kritis, analisis, dan kreatif dalam pemecahan masalah melalui pengembangan kemampuan berpikir. Hal ini relevan dengan pernyataan Gibson, bahwa perubahan keadaan yang non-linier tidak dapat diantisipasi hanya dengan cara berpikir linier melainkan perlu kreativitas, sehingga pendidikan masa depan seharusnya diarahkan pada sistem pendidikan yang memungkinkan peserta didik dapat mengaktualisasi potensi dirinya. Dengan demikian untuk menyelaraskan tujuan pembelajaran dengan tuntutan zaman, guru perlu memahami arah tuntutan pembelajaran terkini agar pembelajarannya lebih bermakna ( Sudarisman 2015 ).

Menurut (Siagian et al 2012), hasil belajar dipengaruhi oleh interaksi antara metode pengajaran dan kondisi pengajaran, hal-hal yang termasuk metode pengajaran antara lain strategi pengorganisasian, strategi pengelolaan pembelajaran 
dan penyampaian. Selanjutnya hal-hal yang termasuk kondisi pengajaran adalah karakteristik siswa, karakteristik isi pengajaran, kendala pengajaran, dan berbagai kondisi lain dalam proses pembelajaran, ada dua faktor yang sangat berpengaruh terhadap hasil belajar siswa, yaitu kualitas pembelajaran dan karakteristik siswa. Upaya mengetahui adanya gaya belajar seorang anak dapat dilihat ketika kegiatan belajar mengajar berlangsung. Seorang guru seharusnya mengetahui bahwa adanya berbagai macam perbedaan gaya belajar yang dimiliki masingmasing anak sehingga menentukan model pembelajaran,metode ataupun strategi yang akan disesuaikan dengan murid yang berbagai macam karakteristiknya sehingga menciptakan hasil pembelajaran yang baik.

Dari survei awal yang dilakukan peneliti dan wawancara dengan salah satu guru yang mengajarkan mata pelajaran biologi kelas XI SMA Negeri 4 Medan, setiap siswa berbeda respon dalam pembelajarannya ada yang ketika guru menjelaskan lebih kepada menggunakan penglihatannya untuk mengerti materi yang dijelaskan oleh guru, ada juga siswa yang lebih menggunakan pendengaran untuk mengerti materi, tetapi ada juga yang respon lebih kepada terjun langsung praktikum dalam belajar. Pada siswa yang gaya belajarnya kinestetik mempunyai analisis yang bagus dalam belajar, kontekstual,dan kritis. Sedangkan, siswa yang gaya belajarnya visual lebih konseptual dalam belajarnya. Selain itu, berdasarkan data hasil belajar siswa yang dilihat dari nilai raport hasil belajar biologi semester ganjil tahun pelajaran 2016/2017 rata-rata di beberapa kelas seperti dikelas XI MIA 7, 8, 9, 10 memperoleh nilai 73 dimana KKM pada pembelajaran ini adalah 75 .

Penulis menyadari penting untuk dilakukan penelitian mengenai analisis gaya belajar dan hubungannya terhadap hasil belajar biologi siswa diharapkan mampu memaksimalkan pembelajaran kedepannya. Penelitian ini diharapkan mampu memberikan informasi untuk memaksimalkan pembelajaran pada sub bab- sub bab yang memiliki banyak konsep sulit seperti materi Sistem Reproduksi Manusia. Hasil penelitian diharapkan mampu membantu dalam pengambilan keputusan pembelajaran secara tepat, mengingat karakteristik gaya belajar setiap siswa berbeda-beda satu sama lainnya dan juga merupakan salah satu faktor yang berperan penting dalam mempengaruhi pembelajaran,

\section{METODE PENELITIAN}

Populasi dalam penelitian ini adalah seluruh siswa kelas XI MIA SMA Negeri 4 Medan T.P. 2016/2017 yang terdiri dari 10 kelas yang berjumlah 400 orang. Sampel penelitian adalah kelas XI MIA 8 dan XI MIA 9 yang berjumlah 80 orang secara purposif sampling. Penelitian ini merupakan penelitian deksriptif korelasional yaitu melihat ada tidaknya hubungan antara gaya belajar dengan hasil belajar biologi siswa pada materi Sistem Reproduksi Manusia di Kelas XI MIA SMA Negeri 4 Medan T.P. 2016/2017.

Instrumen yang digunakan untuk mengumpulkan data mengetahui gaya belajar siswa digunakan angket gaya belajar sebanyak 50 butir pernyataan yang sebelumnya telah divalidkan kepada validator. Pengumpulan data hasil belajar biologi siswa adalah tes soal pilihan ganda sebanyak 35 butir soal dalam materi Sistem Reproduksi Manusia yang disusun dengan perbandingan sebagai berikut: $\mathrm{C} 1$ (mengingat) sebanyak 40\%, C2 (memahami) sebanyak $20 \%$, C3 (menerapkan) sebanyak 20\%, C4 (menganalisis) sebanyak 10\%, C5 (menilai) sebanyal $5 \%$, dan C6 (mengkreasi) sebanyak 5\% yang telah divalidkan kepada validator.

Pada tahap pengolahan data, Untuk klasifikasi hasil angket jawaban responden diklasifikasi dengan cara memberi bobot pada hasil jawaban berdasarkan skala Likert, pernyataan positif angket SS (Sangat Setuju) nilai 4, S (Setuju) nilai 3, TS (Tidak Setuju) nilai 2, STS (Sangat Tidak Setuju) nilai 1 dan pernyataan negatif angket SS (Sangat Setuju) nilai 1, S (Setuju) nilai 2, TS (Tidak Setuju) nilai 3, STS (Sangat Tidak Setuju) nilai 4. Selanjutnya, hasil tes pilihan ganda diperiksa dan dianalisis dengan cara klasifikasi hasil tes soal, jawaban responden diklasifikasi dengan cara memberi bobot pada hasil jawaban jika menjawab benar diberi nilai 1 dan salah nilai 0 . Sebelum instrument penelitian ini digunakan untuk mengumpulkan data, seperangkat tes tersebut harus 
diuji coba kelayakannya di luar sampel meliputi uji validitas, uji reliabilitas, tingkat kesukaran soal, dan daya beda soal.

Teknik analisis data untuk hasil angket dianalisis secara deskriptif kuantitatif. Untuk hasil angket yang telah diskoring lalu, dilakukan tabulasi interpretasi jawaban angket dengan cara membuat kategori untuk setiap kriteria dan untuk penafsiran tingkat kecenderungan skor masing-masing variabel dihitung dengan menggunakan rata-rata (Xi) dan simpangan baku ideal (SDi). Selanjutnya, dianalisis secara deskriptif persentase dengan menggunakan rumus:

$$
\mathrm{P}=\frac{\mathrm{F}}{\mathrm{N}} \times 100 \%
$$

Keterangan

$\mathrm{P}=$ Persentase antusiasme belajar siswa dari hasil jawaban responden.

$\mathrm{F}=$ Frekuensi atau jumlah skor yang diperoleh responden.

$\mathrm{N}=$ Jumlah skor yang semestinya diperoleh responden (Sudijono 2010).

Selanjutnya, untuk hasil analisis tes dilakukan tabulasi jawaban tes dari seluruh siswa kemudian melakukan interpretasi jawaban tes dengan cara membuat kategori untuk setiap kriteria dan untuk penafsiran tingkat kecenderungan skor masing-masing variabel dihitung dengan menggunakan rata-rata (Xi) dan simpangan baku ideal (SDi), kemudian berdasarkan skor yang diperoleh siswa dapat dianalisis urutan tingkat penguasaan siswa dalam setiap indikator tes pengetahuan pada Materi Sistem Reproduksi Manusia dan berdasarkan tingkat penguasaan siswa dapat dianalisis tingkatan pengetahuan yang terdistribusi dari C1-C6.

\section{Uji Persyaratan Data}

Sebelum dilakukan uji hipotesis terlebih dahulu dilakukan uji prasyarat analisis yaitu uji homogenitas. Kemudian dihitung koefisien korelasi untuk mengetahui berapa besar hubungan antara variabel $\mathrm{X}$ dan variabel $\mathrm{Y}$ menggunakan uji korelasi Product Moment. Dan untuk menguji kebenaran dari hipotesis yang telah diajukan dapat dilakukan dengan memperbandingkan besarnya " $r$ " yang diperoleh dalam proses perhitungan dengan besarnya " $r$ " yang tercantum dalam tabel nilai " $r$ " Product Moment dengan $\alpha=0,05$ yang terlebih dahulu dicari derajat bebasnya ( $\mathrm{df}$ ) dengan rumus: $\mathrm{df}=\mathrm{N}-\mathrm{Nr}=$ banyaknya kelas - banyak variabel yang dikorelasikan.Jika $r_{\text {hitung }}>$ $r_{\text {tabel }}$ maka hipotesis penelitian ( $\mathrm{Ha}$ ) diterima yang berarti ada hubungan yang signifikan (korelasi positif) antara variabel $X$ dan variabel $Y$ dan jika $r_{\text {hitung }}<r_{\text {tabel }}$ maka hipotesis nol $\left(H_{0}\right)$ diterima yang berarti tidak ada korelasi antara variabel $\mathrm{X}$ dan variabel $\mathrm{Y}$ (Arikunto 2006). Kemudian dihitung koefisien determinasi dihitung untuk mengetahui besar kecilnya daya dukung pengaruh antara variabel $X$ terhadap variabel Y.

\section{HASIL PENELITIAN}

Gaya belajar dapat diartikan sebagai kemampuan seseorang untuk memahami dan menyerap pelajaran sesuai dengan kemampuan dan karakter dan caranya sendiri. Berdasarkan hasil analisis data yang diperoleh dari angket mengetahui gaya belajar siswa kelas XI MIA SMA Negeri 4 Medan T.P 2016/2017 dengan jumlah responden 80 orang. Hasil perolehan data gaya belajar secara keseluruhan dapat dilihat pada Tabel 1.

Tabel 1. Penafsiran Skor Variabel Pengetahuan pada Materi Archaebacteria dan Eubacteria (X)

\begin{tabular}{cccccccc}
\hline \multirow{2}{*}{ Keterangan } & Visual & Auditorial & Kinestetik & $\begin{array}{c}\text { Visual- } \\
\text { Kinestetik }\end{array}$ & $\begin{array}{c}\text { Audio- } \\
\text { Kinestetik }\end{array}$ & $\begin{array}{c}\text { Visual- } \\
\text { Audio }\end{array}$ & \begin{tabular}{c} 
VAK \\
\cline { 2 - 7 }
\end{tabular} \\
\cline { 2 - 7 } & 11 & 7 & 3 & 4 & 6 & 9 & 40 \\
\hline $\begin{array}{c}\text { Jumlah Siswa } \\
\text { Persentase } \\
(\%)\end{array}$ & 13,75 & 8,75 & 3,75 & 5 & 7,5 & 11,25 & 50 \\
\hline
\end{tabular}


Berdasarkan Tabel 1 di atas diketahui gaya belajar siswa di kelas XI MIA SMA Negeri 4 Medan tahun pembelajaran 2016/2017 memiliki nilai bervariasi. Terdapat 11 orang siswa $(13,75 \%)$ yang memiliki gaya belajar visual, siswa yang memiliki gaya belajar auditorial terdapat 7 orang siswa (8,75\%), siswa yang memiliki gaya belajar kinestetik terdapat 3 orang siswa (3,75\%). Sesuai pernyataan dari DePorter dan Hernacki (2011), gaya belajar seseorang adalah kombinasi dari bagaimana ia menyerap, dan kemudian mengatur serta mengolah infomasi. Hasil angket gaya belajar yang diberikan kepada siswa didapatkan tidak hanya gaya belajar unimodal visual, auditorial, dan kinestetik yang terdapai. Tetapi, terdapat banyak siswa yang memiliki gaya belajar bimodal dengan memiliki 2 gaya belajar sekaligus untuk memperoleh dan mengolah informasi yang didapatkan. Terdapat 4 orang siswa (5\%) yang memiliki gaya belajar bimodal visual-kinestetik. Selain itu, terdapat 6 orang siswa
(7,5\%) yang memiliki gaya belajar bimodal auditorialkinestetik. Dan terdapat pula $9(11,25 \%)$ orang siswa yang memiliki gaya belajar bimodal visual-auditorial. Selain, terdapat gaya belajar unimodal dan bimodal dari hasil penelitian, terdapat pula siswa yang memiliki gaya belajar dengan ketiga sekaligus tipe gaya belajar yang sering disebut dengan gaya belajar trimodal (VAK), terdapat 40 orang siswa (50\%). Jika dibandingkan dari semua hasil siswa yang memiliki beberapa tipe gaya belajar, gaya belajar trimodal (VAK) ini lah yang mempunyai data tertinggi dari datadata gaya belajar lainnya.

Maka, dapat disimpulkan bahwa terdapat gaya belajar siswa kelas XI MIA SMA Negeri 4 Medan yang berbeda-beda. Selanjutnya data hasil gaya belajar di SMA Negeri 4 Medan tahun pembelajaran 2016/2017 secara visual dapat dilihat pada Gambar 1. di bawah ini.

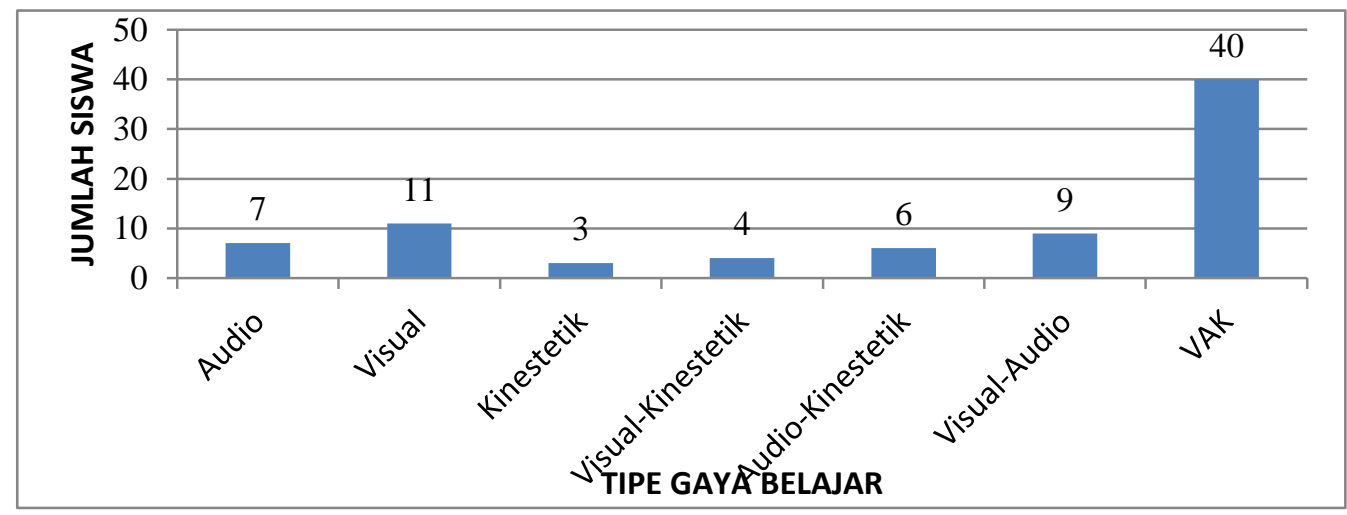

Gambar 1. Grafik Hasil Gaya Belajar Sisiwa

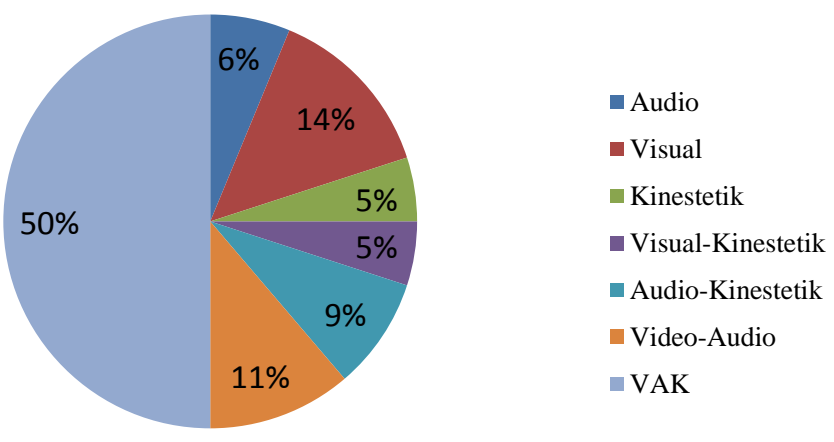

Gambar 2. Diagram Persentase Hasil Gaya Belajar 
Halaman : $090-099$

Data hasil belajar diperoleh dari instrumen tes, diketahui nilai tertinggi sebesar 90 dan nilai terendah sebesar 60, dengan rata-rata sebesar 78,19 dan standart deviasinya sebesar 8,58 serta varias sebesar 73,61. Penafsiran skor dari nilai hasil belajar siswa dapat dilihat pada Tabel 4 di bawah ini.

Tabel 2. Frekuensi Hasil Belajar Siswa (Y)

\begin{tabular}{ccccc}
\hline No & Interval nilai & F. Absolut & F. Relatif & Kategori \\
\hline 1 & $90-100$ & 9 & 12 & Sangat Tinggi \\
2 & $80-89$ & 27 & 34 & Tinggi \\
3 & $70-79$ & 29 & 36 & Sedang \\
4 & $60-69$ & 15 & 18 & Rendah \\
5 & $50-59$ & 0 & 0 & Sangat Rendah \\
\hline & Jumlah & 80 & $100 \%$ & \\
\hline
\end{tabular}

Berdasarkan Tabel 2 diatas diketahui data hasil belajar biologi siswa kelas XI MIA SMA Negeri 4 Medan T.P 2016/2017, memiliki nilai yang bervariasi, dimana sebagian besar berada pada kategori sedang 70-79 dengan frekuensi 29 orang siswa (34\%), skor yang dibawah rata-rata sebanyak 15 orang siswa (18\%), dan skor diatas rata-rata sebanyak 36 orang siswa (46\%).
Dari hasil distribusi frekuensi tersebut maka dapat disimpulkan bahwa data hasil belajar siswa kelas XI MIA SMA Negeri 4 Medan tergolong cukup. Selanjutnya penyebaran distribusi frekuensi data hasil belajar belajar siswa kelas XI MIA SMA Negeri 4 Medan T.P. 2016/2017 secara visual dapat dilihat Gambar 3.

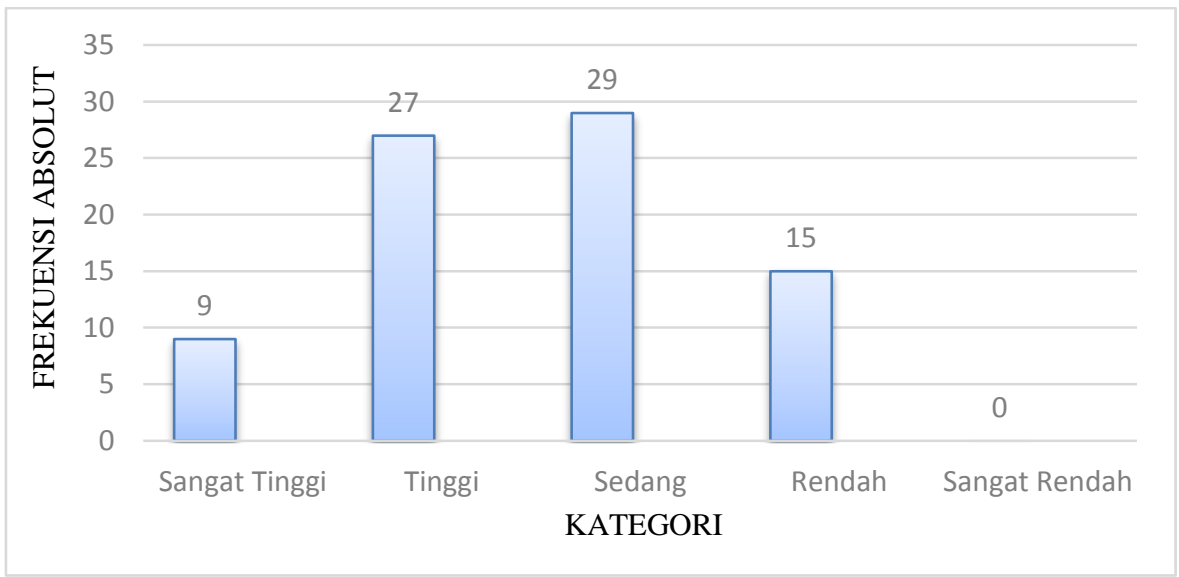

Gambar 3. Diagram Tingkat Hasil Belajr Siswa

\section{Hasil Uji Persyaratan Data}

Pengujian homogenitas dilakukan untuk mengetahui variasi populasi bersifat homogen jika $F_{\text {hitung }}<F_{\text {tabel }}$ yang dikonsultasikan pada tabel distribusi $F$ dengan taraf signifikan $\alpha=0,05$. Hasil perhitungan uji homogenitas data variabel gaya belajar dan hasil belajar membuktikan bahwa $\mathrm{F}$ tabel dengan varians $=$ 3,44 dan 6,36 sebesar 1,447728 maka $F$ hitung $<F_{\text {tabel }}$ yaitu $0,540881<1,447728$. Dengan demikian dapat disimpulkan bahwa data tersebut memiliki varians yang seragam (Homogen).

\section{Perhitungan Koefisien Korelasi dan Uji Hipotesis Penelitian}

Perhitungan koefisien korelasi dilakukan dengan analisis korelasi product moment. Hipotesis nol ( $\mathrm{Ho}$ ) diterima dan menolak hipotesis alternatif $(\mathrm{Ha})$ apabila nilai $r_{\text {hitung }}<r_{\text {tabel }}$ dan sebaliknya hipotesis 
alternatif( $\mathrm{Ha})$ akan diterima dan menolak hipotesis nol (Ho) apabila $r_{\text {hitung }}>r_{\text {tabel, }}$ jika dilihat dari jumlah sampel $\mathrm{N}=80$, pada tingkat signifikasi $5 \%$ diperoleh $r_{\text {tabel }}$ sebesar 0,220, karena $r_{\text {hitung }}>r_{\text {tabel }}(2,23>0,220)$ maka disimpulkan bahwa ada hubungan yang signifikan antara gaya belajar dengan hasil belajar biologi siswa kelas XI MIA SMA Negeri 4 Medan tahun pelajaran 2016/2017.

Untuk menguji uji hipotesis digunakan digunakan dengan penerimaan $\mathrm{Ha}$ jika $t_{\text {hitung }}>t_{\text {tabel }}$ dan sebaliknya tolak Ha jika $t_{\text {hitung }}<t_{\text {tabel. }}$. Dari hasil pengujian hipotesis diketahui bahwa $t_{\text {hitung }}>t_{\text {tabel }}(9,89>1,67)$ sehingga dalam penelitian ini $\mathrm{Ha}$ diterima sekaligus menolak Ho yang berarti bahwa ada hubungan gaya belajar terhadap hasil belajar biologi siswa kelas XI MIA SMA Negeri 4 Medan tahun pembelajaran 2016/2017.

\section{Perhitungan Indeks Determinasi}

Dengan diterimanya korelasi yang menyatakan terdapat hubungan antara gaya belajar dengan hasil belajar siswa. Untuk mengetahui seberapa besar konstribusi gaya belajar terhadap hasil belajar biologi siswa pada materi Sistem Reproduksi Manusia, dapat dihitung dengan menggunkan harga indeks determinasi (I) yaitu: $\mathrm{I}=\mathrm{r}^{2}$ $x 100 \%=(2,2)^{2} \times 100 \%=48 \%$. Dari hasil perhitungan koefisien korelasi diperoleh harga indeks determinasi (I) yaitu, $48 \%$ yang artinya sebesar $48 \%$ gaya belajar siswa memberikan kontribusi dari faktor gaya belajar dan sisanya yakni $52 \%$ lagi ditentukan oleh faktorfaktor lain yang pada kesempatan ini tidak diketahui.

\section{PEMBAHASAN}

Dari hasil analisis data penelitian gaya belajar dan hubungannya dengan hasil belajar biologi diperoleh bahwa terdapat berbagai gaya belajar yang dimiliki oleh siswa-siswi di kelas XI MIA SMA Negeri 4 Medan. Dari hasil angket terdapat berbagai gaya belajar diantaranya ada yang termasuk unimodal hanya 1 dimensi yang dimiliki (visual, auditorial, kinestetik, selain unimodal terdapat siswa yang memiliki gaya belajar bimodal gabungan dari 2 gaya belajar (auditorial-kinestetik, visual-auditorial dan visual kinestetik) dan juga terdapat siswa yang memiliki ketiga gaya belajar sekaligus yang disebut gaya belajar trimodal (VAK).

Penelitian ini juga menghitung data tentang hubungan gaya belajar dengan hasil belajar biologi siswa kelas XI MIA SMA Negeri 4 Medan T.P. 2016/2017 dari data yang diperoleh korelasinya diantaranya terdapat data gaya belajar visual terhadap hasil belajar adalah sebesar 1,48, untuk gaya belajar auditorial hasil korelasinya sebesar 0,741 , dan terakhir untuk gaya belajar kinestetik data korelasi sebesar 19,154 sedangkan, untuk korelasi ke tiga gaya belajar tersebut sebesar 2,237 dengan rtabel>rhitung $(0,220)$. Dengan melihat hasil pengujian koefisien korelasi dan hipotesis sebesar 9,89>1,67 maka, secara langsung dalam penelitian ini Ho ditolak sekaligus menerima $\mathrm{Ha}$ yang berarti bahwa hubungan gaya belajar terhadap hasil belajar biologi siswa kelas XI MIA SMA Negeri 4 Medan terbukti berarti dan signifikan pada $\alpha=0,05$. Dan data yang didapatkan termasuk homogen dengan nilai sebesar Ftabel<Fhitung 1,447<0,540. Selain itu, terdapat kontribusi sebesar $48 \%$ gaya belajar terhadap hasil belajar biologi siswa.

Menurut Nzesei (2015), manusia belajar dari apa yang dibaca dengan persentasi $10 \%$, mendengar $20 \%$, melihat 30\%, melihat dan mendengar(50\%), melakukan dan mendengar 90\%. Sehingga dapat disimpullkan bahwa dalam diri manusia itu sendiri terdapat gaya belajar unimodal, bimodal maupun trimodal yang dimiliki. Seseorangnya yang sudah mengetahui gaya belajar dalam dirinya akan lebih muda bagaimana cara untuk mengolah dan mengatur informasi yang telah didapatkan.

Dari data agket yang diperoleh terdapat 11 orang siswa $(13,75 \%)$ yang memiliki gaya belajar visual, siswa yang memiliki gaya belajar auditorial terdapat 7 orang siswa $(8,75 \%)$, siswa yang memiliki gaya belajar kinestetik terdapat 3 orang siswa $(3,75 \%)$. Sesuai pernyataan dari DePorter dan Hernacki (2011), gaya belajar seseorang adalah kombinasi dari bagaimana ia menyerap, dan kemudian mengatur serta mengolah infomasi. Hasil angket gaya belajar yang diberikan kepada siswa didapatkan tidak hanya gaya belajar unimodal visual, auditorial, dan kinestetik yang terdapai. Tetapi, terdapat banyak 
siswa yang memiliki gaya belajar bimodal dengan memiliki 2 gaya belajar sekaligus untuk memperoleh dan mengolah informasi yang didapatkan. Terdapat 4 orang siswa $(5 \%)$ yang memiliki gaya belajar bimodal visual-kinestetik. Selain itu, terdapat 6 orang siswa $(7,5 \%)$ yang memiliki gaya belajar bimodal auditorialkinestetik. Dan terdapat pula $9(11,25 \%)$ orang siswa yang memiliki gaya belajar bimodal visual-auditorial. Selain, terdapat gaya belajar unimodal dan bimodal dari hasil penelitian, terdapat pula siswa yang memiliki gaya belajar dengan ketiga sekaligus tipe gaya belajar yang sering disebut dengan gaya belajar trimodal (VAK), terdapat 40 orang siswa (50\%). Jika dibandingkan dari semua hasil siswa yang memiliki beberapa tipe gaya belajar, gaya belajar trimodal (VAK) ini lah yang mempunyai data tertinggi dari datadata gaya belajar lainnya.

Dari hasil penelitian untuk mengetahui hubungan gaya belajar dengan hasil belajar menggunakan perhitungan dengan 2 variabel yaitu nilai terendah dan tertinggi yang dihitung berdasarkan hasil jawaban siswa dari instrumen angket dan tes Siswa yang memiliki gaya belajar auditorial perhitungan skor rata-rata hasil belajar yaitu sebesar 79.80, siswa yang memiliki gaya belajar bimodal auditorial-kinestetik mempunyai rata-rata hasil belajar 79,43, siswa yang memiliki gaya belajar visual ratarata hasil belajar sebesar 78,73, siswa yang memiliki visual-kinestetik rata-rata nilai hasil belajar 75.00, visual-auditorial sebesar 83,22. Sedangkan siswa yang memiliki gaya belajar trimodal (VAK) rata-rata hasil belajarnya adalah 79,97. Jadi dapat disimpulkan bahwa siswa SMA Negeri 4 Medan memiliki hasil belajar berdasarkan gaya belajar yang berbeda-beda.

Hasil penelitian ini menunjukkan bahwa siswa yang memiliki gaya belajar trimodal (VAK) memiliki data tertinggi dari data gaya belajar lainnya yang didapatkan dari hasil angket tetapi, jika dihubungkan dengan hasil belajar dari siswa yang memiliki gaya belajar (VAK) tidak setinggi data gaya belajarnya. selain itu ketidakjujuran siswa dalam menjawab angket dan tes juga bisa menjadi salah satu faktor pengaruh data yang didapatkan gaya belajar terhadap hasil belajar mahasiswa.
Konsep dari gaya belajar adalah diferensiasi individu dalam belajar yang berdasarkan cara yang dipilih oleh individu itu sendiri untuk dipakai pada fase yang berbeda dalam sikus belajar. Setiap individu memiliki gaya belajar yang mendominasi dengan berbeda satu sama lainnya, hal ini disebabkan karena, adanya perbedaan faktor hereditas, pengalaman dan juga bergantung pada lingkungan. Pemakaian gaya belajar oleh individu sebenarnya merupakan sarana untuk memfasilitasi agar belajar dapat mencapai tujuannya, maka setiap individu mempunyai cara tersendiri yang dipilih sesuai dengan dirinya.

Dari keseluruhan deskripsi dan analisis data, maka dapat disimpulkan bahwa setiap siswa memiliki perbedaan gaya belajar dan perbedaan gaya belajar tersebut memberikan kontribusi yang berarti terhadap hasil belajar siswa.

\section{KESIMPULAN}

Hasil penelitian menunjukkan bahwa pada tingkat pengetahuan terbesar sebesar 51,25\% yaitu sebanyak 41 siswa memiliki tingkat pengetahuan yang cukup dan tertinggi terdapat pada indikator 3 sebanyak $78,75 \%$ dan terendah terdapat pada indikator 2 sebanyak 51,5\%. Sedangkan berdasarkan tingkatan pengetahuan yang terdistribusi dari C1-C6 yang tertinggi adalah tingkatan C2 sebesar $85,4 \%$ dan yang terendah adalah tingkatan C6 sebesar 51,25\%. Tingkatan sikap terbesar sebesar 52,25\% yaitu sebanyak 42 siswa memiliki tingkatan sikap yang cukup baik. Adapun penguasaan sikap paling tinggi terdapat pada tingkatan 3 (menilai) sebanyak 82,43\% dan penguasaan sikap paling rendah terdapat pada tingkatan 5 (karakterisasi) sebanyak 72,3\% serta ada hubungan yang signifikan antara pengetahuan dan sikap siswa pada materi Archaebacteria dan Eubacteria di kelas X SMA Negeri 4 Medan T.P. 2016/2017 yang ditunjukkan dengan harga koefisien korelasi sebesar 0,844 termasuk korelasi dengan kategori tinggi.

\section{UCAPAN TERIMA KASIH}

Terima kasih terkhusus kepada dosen pembimbing, Dra. Cicik Suriani, M.Si yang telah banyak memberikan banyak masukan dan saran 
hingga terselesaikannya penelitian ini. Dan kepada Ibu Eni Susanti, S.Pd selaku guru biologi SMA Negeri 4 Medan yang bimbingannya selama penelitian berlangsung dan siswa-siswi kelas XI MIA 8 dan XI MIA 9 yang telah banyak membantu selama penelitian berlangsung.

\section{DAFTAR PUSTAKA}

Ahmad dan Supriyono., (2004), Psikologi Belajar, Rineka Cipta, Jakarta

Abdurrahman, M., (2010), Pendidikan Bagi Anak Berkesulitan Belajar, Rineka Cipta, Jakarta.

Arikunto, Suharsimi., (2006), Prosedur Penelitian Suatu Pendekatan Praktik, Rineka Cipta, Jakarta.

Arikunto, Suharsimi., (1993), Dasar-Dasar Evaluasi Pendidikan, Bumi Aksara, Jakarta.

Bahrudin dan Wahyuni., (2015), Teori Belajar \& Pembelajaran , Ar-Ruzz Media , Yogyakarta.

Dalyono , M., (2010), Psikologi Pendidikan, Rhineka Cipta , Jakarta

DePorter dan Hernacki., (2011), Quantum Learning : Membiasakan Belajar Nyaman dan Menyenangkan, Kaifa, Bandung.

Hasrul, (2009)., Pemahaman Tentang Gaya Belajar, Jurnal MEDTEK, 1 (2) , 1-9

Ismawati dan Umaya, (2012), Belajar Bahasa di Kelas

Awal, Ombak, Yogyakarta

Khanifatul, (2013), Pembelajaran Inovatif: Strategi Mengelola Kelas Secara Efektif Dan Menyenangkan, Ar-Ruzz Media, Jakarta.

Lestari, A, dkk., (2012), Penerapan Strategi Pembelajaran Matematika Berbasis Gaya Belajar Vak (Visual,Auditorial,Kinestetik), Jurnal Pendidikan Matematika, 1(1), 1-7.

Mardianto., (2012), Psikologi Pendidikan, Perdana Publishing, Medan

Nurhayati, Nunung, (2011), Biologi Bilingual Untuk SMA/MA Kelas XI, Yrama Widya, Bandung.

Nzesei, M., 2015, A Correlation Study Between Learning Styles And Acaddemic Achievement Among Secondary School Students In Kenya, University Of Nairobi
Purwanto., (2006), Psikologi Pendidikan, PT Remaja Rosdakarya, Bandung

Prawihartono dan Hidayati., (2013), Konsep dan Penerapan Biologi SMA/MA Kelas XI, Bumi Aksara, Jakarta.

Rachmawati Z dan Joko., (2013), Pengaruh Model Pembelajaran Berdasarkan Masalah Dan Gaya Belajar (Visual, Auditori Dan Kinestetik) Terhadap Hasil Belajar Siswa Pada Mata Diklat Rangkaian Listrik Di Smkn 1 Cerme Gresik. Jurnal pendidikan teknik elektro 2 (2),677 683.

Rusman., (2013), Belajar dan Pembelajaran Berbasis Komputer Mengembangkan Profesionalisme Abad 21, Alfabeta cv, Bandung.

Rose dan Nichall., (2015), Revolusi Belajar Accelerated Learning For the $21^{s}$ Century, Nuansa Cendekia, Bandung.

Sari, A., (2014) , Analisis Karakteristik Gaya Belajar Vak (Visual, Auditorial, Kinestetik) Mahasiswa Pendidikan Informatika Angkatan 2014 , Jurnal Ilmiah Edutic ,1(1),112.

Siagiaan, S dan Paimin Tanjung, 2012 , Pengaruh Strategi Pembelajaran dan Gaya Belajar Terhadap Hasil Belajar Ipa Kelas VIII Siswa Smp Negeri 1 Dolok Panribuan, Jurnal Teknologi Pendidikan , 5 (2), 1-20.

Sudarisman , S, (2015) , Memahami Hakikat Dan Karakteristik Pembelajaran Biologi Dalam Upaya Menjawab Tantangan Abad 21 Serta Optimalisasi Implementasi Kurikulum 2013 , Jurnal Florea , 2 (1),29-35.

Sudjana, (2001), Metoda Statistika, Tarsito, Bandung Sudijono, A.., (2010), Statistika Pendidikan, Raja Grafindo Persada, Jakarta.

Sagala, S., (2009) , Konsep dan Makna Pembelajaran , Alfabet cv, Bandung.

Slameto, (2013), Belajar dan Faktor-faktor yang Mempengaruhinya, Rhineka Cipta, Jakarta.

Surbakti, Y,R, (2010), Paradigma Pembelajaran Sejarah Berbasis Konstruktivisme, Spps 24 (1),6-23.

Sriyanti, L., (2013), Psikologi Belajar, Ombak, Yogyakarta 
Halaman : $090-099$

Subini, N, (2015), Rahasia Gaya Belajar Orang Besar, Javalitera, Jogjakarta

Sanjaya, W, (2008), Perancanaan dan Desain Sistem Pembelajaran, Kencana, Jakarta.

Uno, B, Hamzah, (2008), Orientasi Baru dalam Psikologi Pembelajaran, PT Bumi Aksara, Jakarta.

Winkel, W,S, (1987) , Psikologi Pengajaran , Gramedia , Jakarta

Wulandari, E, Fitria, (2011) , Pengembangan Media Pembelajaran Biologi Smp Berbasis Komputer Bahan Kajian Sistem Saraf Dan Sistem Indera Pada Manusia , Jurnal Pedagogia 1(1),99-109. 